\title{
The Phenomenon of Homelessness during the Greek Economic Crisis 2009-2018
}

\author{
Symeon N. Mavridis ${ }^{1} \&$ Savvoula I. Mouratidou ${ }^{1}$ \\ ${ }^{1}$ Department of Social Administration and Political Science, Democritus University of Thrace, Komotini, Greece \\ Correspondence: Symeon N. Mavridis, Department of Social Administration and Political Science, Panagi \\ Tsaldari 1, PC 69100, Komotini, Greece. E-mail: s.mavridis@hotmail.com
}

Received: August 22, 2018; Accepted: October 11, 2018; Published: October 29, 2018

\begin{abstract}
This research focuses on the phenomenon of homelessness in Greece, especially during the deep economic crisis that has lasted from 2009 until this day. Unfortunately, in large part, homelessness also affects welfare policy, as well as social cohesion and healthcare. The significance of the study lies in the fact that there are no official data from governmental institutions concerning the number of homeless people across the country. For this reason, this study attempts to collect all available data in order to present the evolution of the phenomenon of homelessness from 2009 to present. Homelessness is examined in relation to poverty and other factors of deprivation. In addition, countermeasures addressing homelessness, adopted by both public and private organizations, are also examined. Public institutions usually provide small pensions, only for seniors over sixty-seven years old, meal cards, free soup kitchens and several shelters. At the same time, a large number of private organizations, such as NGOs, provide free accommodation, meals, and showers. Unfortunately, the rising number of homeless people during the ongoing socioeconomic crisis and the lack of communication among institutions deteriorate the problem. On these grounds, this research analyzes the phenomenon of homelessness in Greece in order to provide the appropriate solutions for its containment.
\end{abstract}

Keywords: unemployment, homelessness, housing, poverty

\section{Introduction}

Greece has been facing serious financial problems since 2009. The general turmoil in the global markets has led to an unprecedented local debt crisis lasting until this day. According to the Eurostat data in 2009 Greece's debtto-GDP ratio had reached $126.7 \%$, which meant that the general government gross debt had amounted to $€ 301$ billion. In 2016 the Greek debt reached $180.8 \%$ of GDP, namely over $€ 315$ billion. Despite the fact that three International Economic Programs, as well as massive reforms, have been introduced by the Greek governments, the country still fights for its economic and financial stability (Mavridis 2018:1). Unfortunately, the impact of the crisis was devastating in real life. The welfare reforms brought about major cuts in pensions and wages, thus, deepening poverty (Petmesidou 2011:4-5, 2012:8-10, 2013a:2, 2013b:7-10, 2014:16). In reality, social conditions have significantly deteriorated resulting into homelessness, poverty, migration, unemployment, suicides and generally speaking social exclusion (Mavridis 2018:1). "Growing unemployment and falling income have increased vulnerability to homelessness as more people are unable to meet housing costs. Austerity measures and cuts have had a major impact on service capacity at a time of growing demand" (FEANTSA 2012:25). The rise of unemployment affects both homelessness and family relationships (Fitzpatrick et al. 2012:11, 2017:2). In Greece, poor households spend $75 \%$ of their disposable income on housing (FEANTSA and the Foundation Abbé Pierre 2018:53). Data is impressive. "More than $40 \%$ of the population and almost all poor households $(91.9 \%)$ were overburdened by housing costs in 2016, i.e. an increase of 380\% between 2010 and 2016 for non-poor households" (FEANTSA and the Foundation Abbé Pierre 2018:55).

What is more, since 2016 EU has closed the borders to immigrants through Greece. The closing of Greek borders has caused an additional negative impact on general homelessness. On 30 November 2016, 32,535 people were registered in the Greek refugee camps (FEANTSA and the Foundation Abbé Pierre 2017:16). According to the Ministry of Digital Policy, Telecommunications and Media on 1 January 2017, 62,784 refugees were registered in organized camps and on 30 July 2017, 62,407. 


\section{Methodology}

The research uses secondary data, in particular previously written data, reports, articles and other relevant literature sources such as books and the Internet. Precious statistical data was drawn from Eurostat, OECD, the Ministry of Justice and the Court of First Instance of Thessaloniki. Also, data from five older surveys on Greek homelessness were compared. The former surveys were conducted by the City of Athens Reception and Solidarity Center for the Homeless (KYADA), NGO Klimaka and Panteion University of Athens with the collaboration of the Ministry of Labour, Social Insurance and Social Solidarity. It should be noted at this point that there is no official information or published data from government agencies concerning the phenomenon of homelessness. Furthermore, it should be taken under consideration that there is both visible and invisible homelessness since many vulnerable people, who are at obvious risk of homelessness, are accommodated by friends and relatives. Limitations are related firstly to the lack of a consistent definition of homelessness and there is also a difficulty in measuring homelessness, specifically for those who are either temporarily accommodated by relatives and friends, invisible homeless people or people at risk of homelessness.

\section{International and Constitutional Protection of Housing}

Homelessness is a dangerous situation for society. It promotes poverty and social exclusion. In legal theory adequate housing is traditionally regarded as a social right. In the past the UNO tried to mitigate the global repercussions of homelessness. First, in 1948 the Universal Declaration of Human Rights (UDHR) defined in article 25 that: "Everyone has the right to a standard of living adequate for the health and well-being of himself and of his family, including food, clothing, housing and medical care and necessary social services, and the right to security in the event of unemployment, sickness, disability, widowhood, old age or other lack of livelihood in circumstances beyond his control". Moreover, in 1966 the United Nations General Assembly adopted the International Covenant on Economic, Social and Cultural Rights (ICESCR). ICESCR is a multilateral treaty which defines in article 11, paragraph 1 that: "The States Parties to the present Covenant recognize the right of everyone to an adequate standard of living for himself and his family, including adequate food, clothing and housing, and to the continuous improvement of living conditions. The States Parties will take appropriate steps to ensure the realization of this right, recognizing to this effect the essential importance of international co-operation based on free consent". In the European Union, the EU Charter of Fundamental Rights defines in article 34 (Social security and social assistance), paragraph 3 that: "In order to combat social exclusion and poverty, the Union recognizes and respects the right to social and housing assistance so as to ensure a decent existence for all those who lack sufficient resources, in accordance with the rules laid down by Union law and national laws and practices".

Furthermore, with regard to the Greek Constitution with its amendments (1975-1986/2001/2008), the right to housing is clearly guaranteed in article 21 , paragraph 4 . In particular, constitutional article 21 , paragraph 4 stipulates that: "The acquisition of dwelling for those that deprive it or those inadequately sheltered is subject to special care by the State". Also, the Greek legislation protects to an extent main residence (first residence) from auctions by Law 3869/2010 and its amendment (L. 4336/2015 and L. 4346/2015). The protection covers only natural persons who are not traders/merchants. "Some 60,000 households were placed under the protection of this law between 2011 and 2013" (FEANTSA and the Foundation Abbé Pierre 2017:85). Besides, to some extent, both natural and legal persons, either with commercial status or not, are protected by Law 4469/2017 which establishes a permanent out-of-court debt settlement mechanism.

In addition, Law 4320/2015 on "measures to deal with the humanitarian crisis" mentioned that vulnerable households facing extreme poverty were exempt from paying electricity up to 1,200 kwh per bill (article 1). Also, this Law's article 2 granted rental allowance to up to 30,000 people, individuals or families, living in extreme poverty conditions. Every month, an individual could receive up to $€ 70$ and families up to $€ 220$ in benefits. Benefits were directly paid to the home owner (article 2) while article 3 concerned food support (food cards). In mid 2016 the provisions of Law 4320/2015 were practically replaced by Law 4389/2016 (Official Government Gazette A' 94/27.05.2016, especially as to article 235) on the Social Solidarity Income (in Greek KEA). The SSI mainly provides at least $€ 200$ per month to every individual with very low or zero income facing extreme poverty. Half of the amount is mandatorily given via prepaid bank cards. As of 11 July 2018, 4,871 homeless people received the SSI.

Moreover, according to Law 4387/2016 (art. 93), the state provides a special pension of $€ 360$ to uninsured seniors over 67 years old (social solidarity allowance). Finally, according to Ministerial Decisions (Г3/oเк2615/22-051985, Official Government Gazette 329 B'/29-05-1985 and Г3/oıк2435/08-07-1987, Official Government Gazette 435 B'/19-08-1987) based on Legislative Decree 162/1973 (on measures for the protection of the elderly and 
chronically ill), homeless people over 65 , uninsured and poor, single or married, may only receive a rental allowance. If married at least one of them must be over 65 . Of course, the fact that aid is linked to a specific age threshold causes problems since the homeless less than 65 years old are de facto excluded from financial support. Finally, according to Law 4472/2017 (Official Government Gazette 74 A'/19-05-2017) the state provides a special rental allowance to up to 600,000 households paying rent or burdened with the cost of servicing a first home mortgage loan (art. 3).

\section{Who is Considered Homeless?}

Who is considered as homeless? There are various definitions of homelessness (Eddowes and Hranitz 1989, Chamberlain and Mackenzie 1992, Roth et al. 1992, Jencks 1994, Edgar et al. 2004, Wyly and Hammel 2005, Toro 2007, Minnery and Greenhalgh 2007, Ravenhil 2008, McNaughton 2008, Murphy and Tobin 2011). "Homelessness is defined as including anyone whose night residence is either in a shelter, on the street or in another public place" (Eddowes and Hranitz 1989:197). Jencks (1994:4) supported that "the homeless can be divided into two groups: those who sleep in free shelters (the 'shelter homeless') and those who sleep in places not intended for human habitation, such as bus stations, subway trains, automobiles, doorways, and abandoned buildings" the "street homeless'. According to Murphy and Tobin (2011:9) "homelessness is the absence of a home or lack of a stable, dependable, source of housing". The United Nations Economic Commission for Europe (2009) classifies homeless people into two categories: a) primary homelessness or rooflessness (people living on the streets without a shelter) and b) secondary homelessness (people with no place of usual residence).

According to Greek Law 4052/2012 (article 29, paragraphs 1 and 2):

1. The homeless are recognized as a vulnerable social group, which is provided for by social protection. The homeless are defined as all persons legally residing in the country with no access, or with unsafe access to adequate, privately owned, rented or bestowed housing that meets the required specifications and has basic water services and electricity.

2. The homeless include especially those who live on the street, in hostels, are hosted, out of necessity, temporarily in institutions or other closed structures as well as those living in inappropriate accommodation" (Theodorikakou et al., 2013, 204).

Apart from the Greek legislation, in 2005 the European Federation of National Organizations Working with the Homeless (FEANTSA) launched a European Typology on Homelessness and Housing Exclusion (ETHOS). The ETHOS typology distinguishes four basic categories: Roofless, Houseless, Insecure and Inadequate (FEATSA 2006:1, Stamatis 2012:5-6, Arapoglou et al. 2005:22). In a survey conducted by Arapoglou and Gounis in 20132014 in Attica (Arapoglou and Gounis 2014) the data followed the ETHOS typology on homelessness.

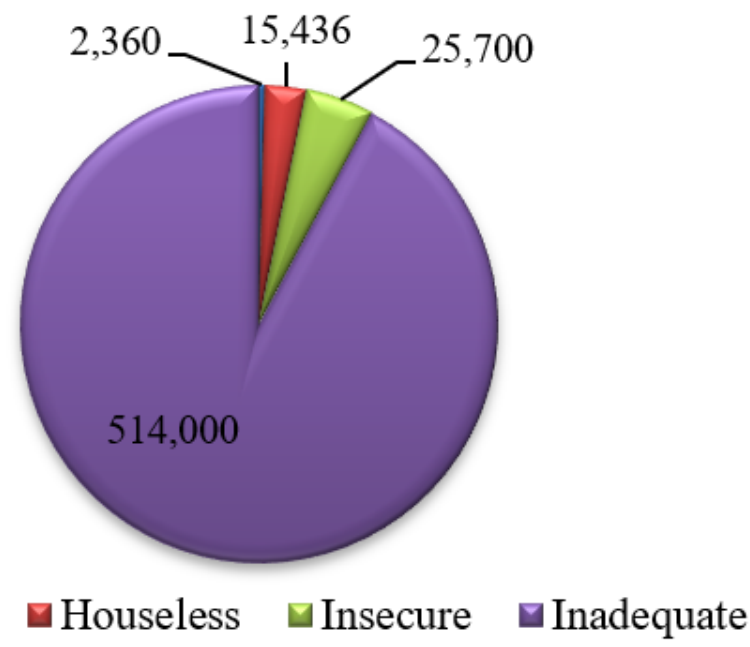

Figure 1. Homelessness in Attica 2014 based on ETHOS - European Typology on Homelessness and Housing Exclusion

Source: Arapoglou and Gounis 2014, Arapoglou et al. 2015:25-27, authors' editing 
Table 1. Homelessness in Attica 2014 based on ETHOS - European Typology on Homelessness and Housing Exclusion

\begin{tabular}{llll}
\hline Conceptual Category & & Operation Category & People \\
\hline ROOFLESS & 1 & People living rough & 2,360 \\
HOUSELESS & 3 & People in accommodation for the homeless & 15,436 \\
INSECURE & 8 & People living in insecure accommodation & 25,700 \\
INADEQUATE & 11 & People living in temporary / non-standard structures & $93,820-514,000$ \\
\hline
\end{tabular}

Source: Arapoglou and Gounis 2014, Arapoglou et al., 2015:25-27

In 2015, in Attica province (including Athens) the number of homeless people according to the ETHOS typology was 500,000 (FEANTSA and Foundation Abbé Pierre 2018:98).

\section{Housing Problems in Europe}

In Europe it is estimated that there are approximately 4 million people who are homeless (Saltou 2016). "Homelessness, once considered a problem confined to Third World nations and to periods of war and economic depression, has recently emerged as a major social issue in most developed nations" (Toro 2007:461). The basic problem in Europe is that homelessness is not confronted as a serious problem. "In Europe there are very few strategic approaches to homelessness. In fact, homelessness is often not considered as worthy of a policy response in its own right and may be relegated to the periphery of both housing and social policy arenas" (Minnery and Greenhalgh 2007:650). As far as the world is concerned, the homeless are estimated at 100 million. Greece is not the only EU member confronting problems with the phenomenon of homelessness. In many countries people cannot afford the high costs of home maintenance and face the dangers of housing deprivation.

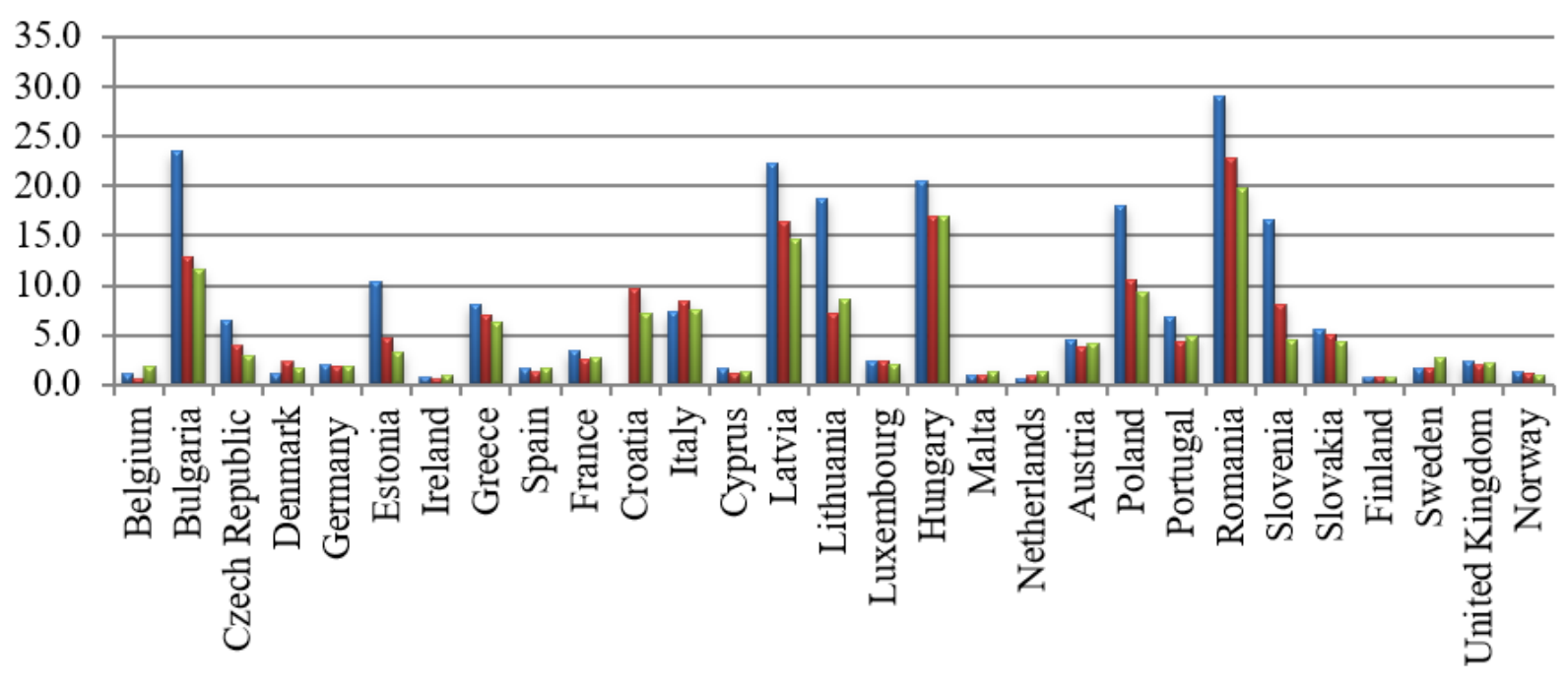

\section{$\square 2008 \square 2012 \square 2016$}

Figure 2. Severe Housing Deprivation Rate in Europe \% (Total)

Source: Eurostat, authors' editing

Figure 2 shows that states from the former Eastern Bloc, such as Hungary, Romania, Latvia, Bulgaria, are significantly affected from housing deprivation. On the other hand, the abovementioned states have significantly progressed between 2008 and 2016. Mediterranean states, such as Greece, Italy and Portugal, are also vulnerable to housing deprivation but to a lesser extent. In 2006 6.3\% of the population in Greece faced severe housing deprivation problems. The severe housing deprivation rate is the percentage of population living in a dwelling considered to be overcrowded, while also exhibiting at least one of the housing deprivation measures. Housing deprivation is a measure of poor amenities and is calculated by referring to those households with a leaking roof, no bath/shower and no indoor toilet, or a dwelling considered too dark. 
45.00

40.00

35.00

30.00

25.00

20.00

15.00

10.00

5.00
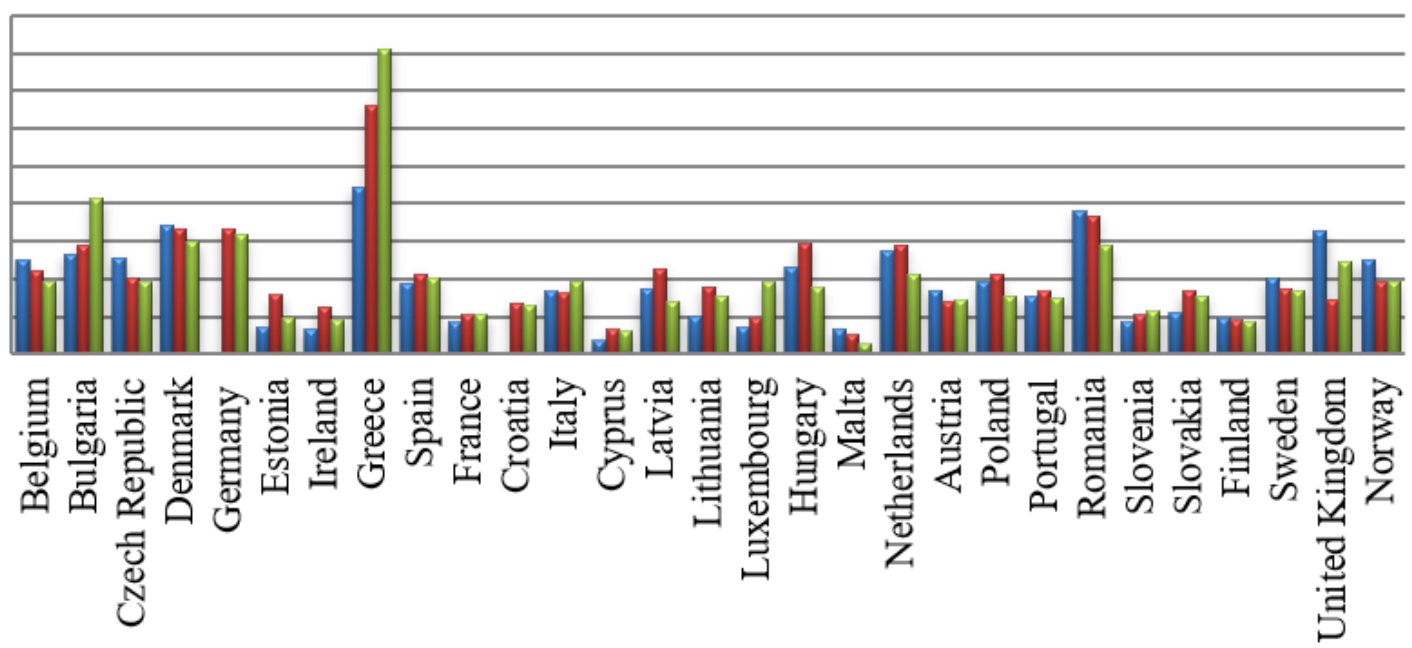

\section{口2008 $\square 2012 \square 2016$}

Figure 3. Housing Cost Overburden Rate in Europe (Total in Percent)

Source: Eurostat, authors' editing

Figure 3 shows that many citizens in Greece, amounting to $40.5 \%$ of the population in 2016 (the highest rate in Europe), face serious problems in affording housing costs. The housing cost overburden rate (\%) is the percentage of the population living in a household where total housing costs (net of housing allowances) represent more than $40 \%$ of the total disposable household income (net of housing allowances).

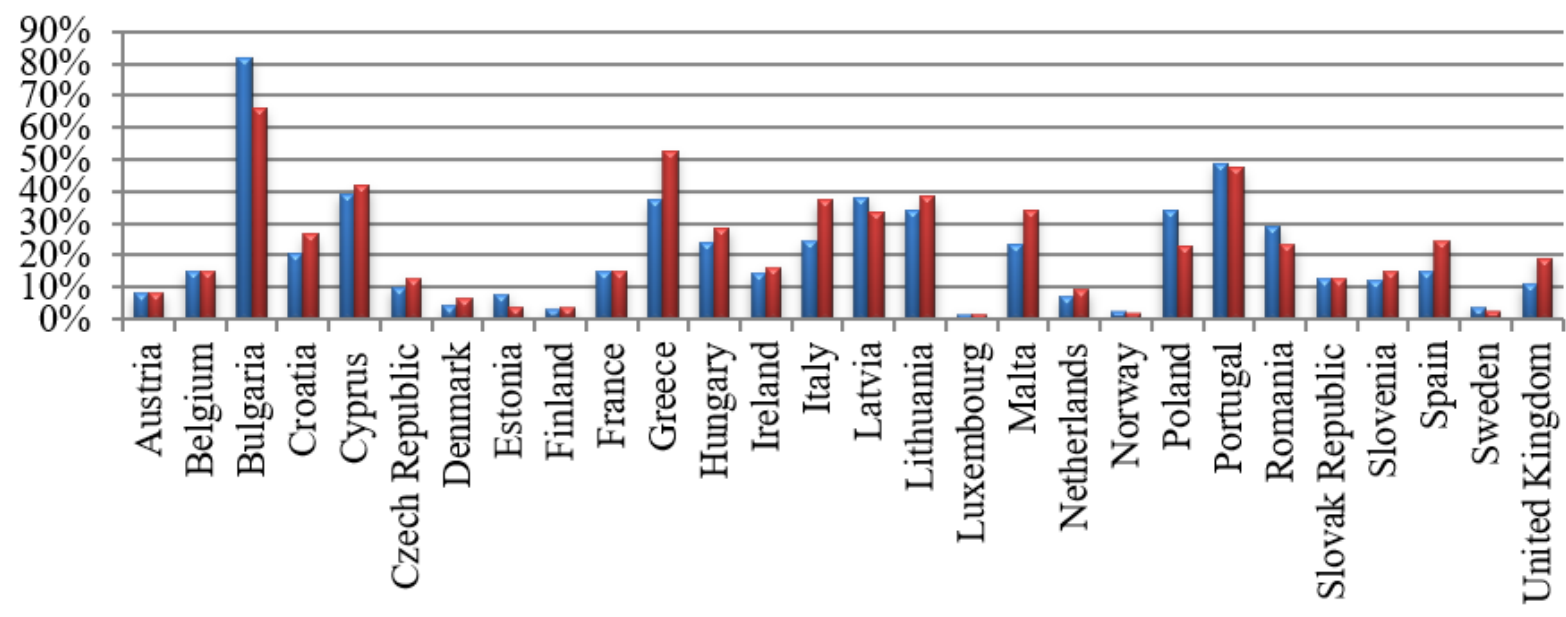

abottom quintile $2010 \quad$ bottom quintile 2014

Figure 4. Difficulties in keeping the dwelling warm 2010-2014 (except Germany)

Source: OECD, authors' editing

Figure 4 depicts the percentage of households that cannot afford to keep their dwelling adequately warm, presenting the bottom quintile of the disposable income distribution. Figure 4 is related to Figure 2 with the exception of Bulgaria. Greece's residents are the most affected by the economic crisis and mainly express inability to keep the dwelling warm. What is worse, although Bulgaria year after year has improved income and living conditions, Greece's statistics have deteriorated between 2010 and 2014, especially for the bottom quintile of the population. Approximately, one in two people from the poorest categories of the Greek population (bottom quintile) cannot afford the costs of keeping their dwelling warm. Also, the phenomenon of homelessness, during 2010-2014, has deteriorated in almost all countries where special Economic Adjustment Programs were implemented such as 
Greece (2010), Cyprus (2011), Spain (2012) and Ireland (2010), while in Portugal (2011) conditions have been critical.

It is confirmed that some welfare regimes in Europe provide significant support to homeless citizens while others do not. The extent of homelessness depends on the support of each welfare regime. Specifically, in northern and richer states homelessness is dealt with better than in the Mediterranean States. Similarly, in the post socialist states the measures against homelessness are in large part inadequate (Busch-Geertsema et al. 2010:17, Fitzpatrick et al. 2012:12).

\section{Homeless in Greece}

\subsection{Categories of Homeless People}

At the beginning of the 1990s, homelessness in Greece was related to foreigners, especially immigrants (Theodorikakou et al. 2013:205). Today, and especially after the adoption of the first Memorandum of Understanding between Greece and its creditors, the majority of homeless are Greeks (KYADA 2016, Panteion University and Ministry of Labour, Social Insurance and Social Solidarity 2018).

Although homelessness has been traditionally related mostly to uneducated poor people, people with mental disorders, drug addicts, alcohol addicts, violent people, unhealthy people and people with family problems, the prolonged Greek economic crisis has brought additional features to homelessness. Specifically, apart from the traditional long-term model of the homeless which mainly consists of drug addicts, alcoholics, compulsive gamblers and people with mental disorders, a new category of homeless people emerged, called the 'neo-homeless' or 'new homeless'. Neo-homeless are people who have been adversely affected by the economic crisis. Many of them were well educated or well-trained and simply lost their jobs (FEANTSA 2012:54, Theodorikakou et al. 2013:206). "The 'new' homeless are characterized by higher levels of qualifications and work experience and do not have complex needs apart from not being able to meet housing costs" (FEANTSA 2012:32). During crisis the phenomenon of homelessness has changed because it has incorporated people who enjoyed a good standard of living in the past, such as freelancers and entrepreneurs). Moreover, except for the unlucky entrepreneurs, many 'new' homeless are simply women and children (Busch-Geertsema et al. 2010:15-16, 55). "The 'new homeless' are defined as families, women, children, youth, seniors, and marginalized ethnic or migrant groups" (Minnery and Greenhalgh 2007:643).

Also, in the last decade, both 'visible' and 'invisible' or 'hidden' homeless people increased in such levels which are unfamiliar to society (Fitzpatrick 2012:23, 2017:17). Hidden homelessness refers to people who try to find at first temporary accommodation through friends or family relatives (Fitzpatrick et al. 2012:82). The major problems which trigger homelessness are economic failures, poverty, high cost of living, housing market conditions, unemployment, and family breakdowns.

\subsection{Active Organizations against Homelessness}

The state, the official Orthodox Church, municipalities, regions, non-profit organizations (NPOs), private organizations such as non-governmental organizations (NGOs) as well as independent groups of individuals try to alleviate the problem of homelessness on a daily basis. Specifically, thousands of free meals are offered by many institutions on a daily basis, such as the Church of Greece, municipalities and NGOs. In 2016, only in the Region of Attica, at least 200 organizations were responsible for providing free meals. For instance, in $2017 \mathrm{NGO}$ "We can" provided 20,000 meals on a daily basis (Mavridis 2018:9). Only in Athens the Reception and Solidarity Center for the Homeless (KYADA) provides 1,200 meals on a daily basis (Saltou 2016). Moreover, some private and public organizations provide free accommodation, night shelters or showers. Following the 2016 Ministerial Decision $\Delta 23$ /oik.19061-1457 (Official Government Gazette B' 1336 12.5.2016) there are only four official types of Homeless Shelters: a) Open Day Shelters for the Homeless, b) Dormitories, c) Transient Hospitality Hostels, and d) supportive apartments. The direct housing provision is very important. Larimer et al. (2009:1355) confirmed that direct housing of citizens, e.g. with alcohol addiction, reduces healthcare costs as well as probable legal costs (court costs, police involvement, etc.). According to the survey of Panteion University and the Ministry of Labour, Social Insurance and Social Solidarity (2018), the majority of homeless people use soup kitchens which provide free meals.

\subsection{The Homeless Population}

Data shows a steady rise in the number of homeless people from 2009 to 2018. It should be noted that the survey of the National Centre for Social Solidarity - NCSS (2009) excluded migrants and travelers (NCSS in FEANTSA and the Foundation Abbé Pierre 2017:16). Unfortunately, illegal immigrants cannot usually be registered for social 
services and so are not identified in certain homelessness surveys based on access to such services (Minnery and Greenhalgh 2007:644).

Table 2. The homeless in Greece, 2009-2018

\begin{tabular}{lll}
\hline Year & Homeless & Sources \\
\hline 2009 & $7,720-11,000$ & $\begin{array}{l}\text { NCSS (2009), FEANTSA and Foundation Abbé Pierre (2017:16), NGO Praxis in } \\
\text { Void Network (2013) }\end{array}$ \\
2010 & $17,000-20,000$ & $\begin{array}{l}\text { Fondeville and Ward (2011:13-14), European Observatory on Homelessness in } \\
\text { Zarafonitou (2012:9), FEANTSA, NGO Klimaka in Reuters (2011) }\end{array}$ \\
2011 & $17,000-20,000$ & Fondeville and Ward (2011:13-14), FEANTSA, NGO Klimaka in Reuters (2011) \\
2012 & 20,000 & FEANTSA (2012:25), Stamatis (2012:5, 11), NGO Klimaka \\
2013 & 20,000 & FEANTSA, NGO Praxis in Void Network (2013) \\
2014 & 25,000 & NGO Praxis (Mavridis 2018:9) \\
2015 & 20,000 & Homeless World Cup Foundation (more than 20,000) \\
2016 & 40,000 & Saltou (2016) \\
2017 & no data & \\
2018 & 40,000 & DiEM25-GR (2018) \\
\hline
\end{tabular}

Data in Table 2, as well as Figure 5, show that Greece has witnessed a serious rise in homelessness over the past years (FEANTSA 2012:21). In Greece, homelessness has increased especially in large urban centers (Theodorikakou et al. 2013:206). In 2018 the political party DiEM25 (Democracy in Europe Movement 2025) supports that there are over 40,000 homeless people. From 2009 to 2018 homeless people have doubled or even quadrupled.

Table 3. The homeless in Athens, Attica, 2010-2018

\begin{tabular}{|c|c|c|}
\hline Year & Homeless & Sources \\
\hline 2010 & 9,000 & European Observatory on Homelessness in Zarafonitou 2012:9 (Attica) \\
\hline 2011 & 10,000 & Mpoulia 2011 (Athens) \\
\hline 2012 & $10,000-13,000$ & $\begin{array}{l}\text { 10,000 Klimaka (Athens), more than 11,000 NGO Praxis in Stamatis 2012:12 } \\
\text { (Athens), 13,000 NGO Praxis in the Daily Star Lebanon } 2012 \text { (Athens) }\end{array}$ \\
\hline 2013 & 9,100 & Arapoglou and Gounis 2015:2 (greater metropolitan area of Athens) \\
\hline 2014 & no data & \\
\hline 2015 & $17,000-20,000$ & $\begin{array}{l}\text { 17,000 FEANTSA 2017b (Attica), 20,000 Kottasova } 2015 \text { (Athens) 17,000 } \\
\text { FEANTSA and Foundation Abbé Pierre 2018:98 (Attica province) }\end{array}$ \\
\hline 2016 & 9,000 & FEANTSA and Foundation Abbé Pierre 2017:16 (Athens) \\
\hline 2017 & 25,000 & Migreurope 2017 (Athens) \\
\hline
\end{tabular}

Table 3 depicts the tremendous rise in homelessness in the greater metropolitan area of Athens. In 2017 the observatory Migreurope counts homeless population at 25,000. Especially in Athens, according to FEANTSA and the Foundation Abbé Pierre (2017:16), "the findings show that 71\% of the Athens homeless were forced to live on the streets in the past five years", which corresponds to $1.4 \%$ of the Athens population. In 2017, in Athens, "1 in 70 people are now homeless, most becoming homeless since 2011" (FEANTSA 2017a). In the near future the issue of homelessness will probably become further deteriorated (Mavridis 2018:9).

\subsection{Major Causes of the Phenomenon of Homelessness}

From a legal point of view the phenomenon of homelessness is on the rise because social rights cannot be judicially enforced. This means that due to a weakness of putting social rights in force the right to housing is practically ineffective (Theodorikakou et al. 2013:203-204). In other words, the homeless cannot make the state provide shelter. Apart from that, in Greece the overall housing policy further deteriorated after the abolition of the former main housing funding body, the Worker's Housing Organization (in Greek OEK) in 2012, which had been established in 1954 !

Moreover, during the Greek crisis the property costs for both owned and rented properties further augmented. In order to collect more revenues, the state introduced new taxes on property such as "ENFIA" which means "Unified 
Property Ownership Tax". This practically means that according to the Independent Authority for Public Revenue almost one out of two taxpayers owes to tax authorities, namely 4,068,857 taxpayers in December 2017 (Kouros 2018).

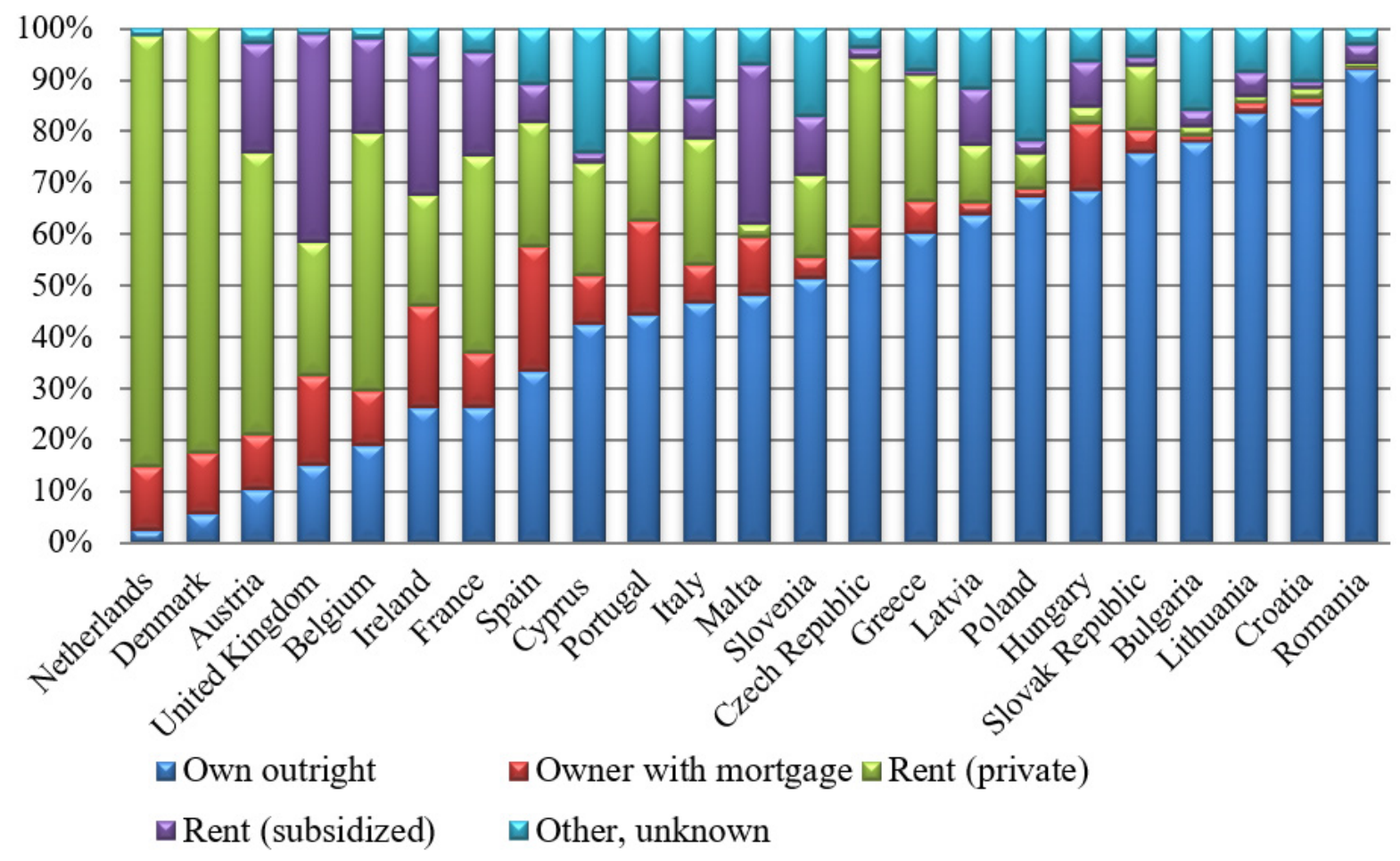

Figure 5. Tenure structure of low-income households with difficulty in keeping the dwelling warm (2014)

Source: OECD, authors' editing

As emphasized in Figure 5, in Greece $60.25 \%$ of the people; who have their own private property, find it difficult to keep their dwelling warm. The calculations are based on the European Survey on Income and Living Conditions (EU SILC 2014) except Germany.

Moreover, the rise in property taxes has led to a tremendous increase in waivers of succession (Figure 6), namely statements renouncing inheritance (there are only estimations for 2017).

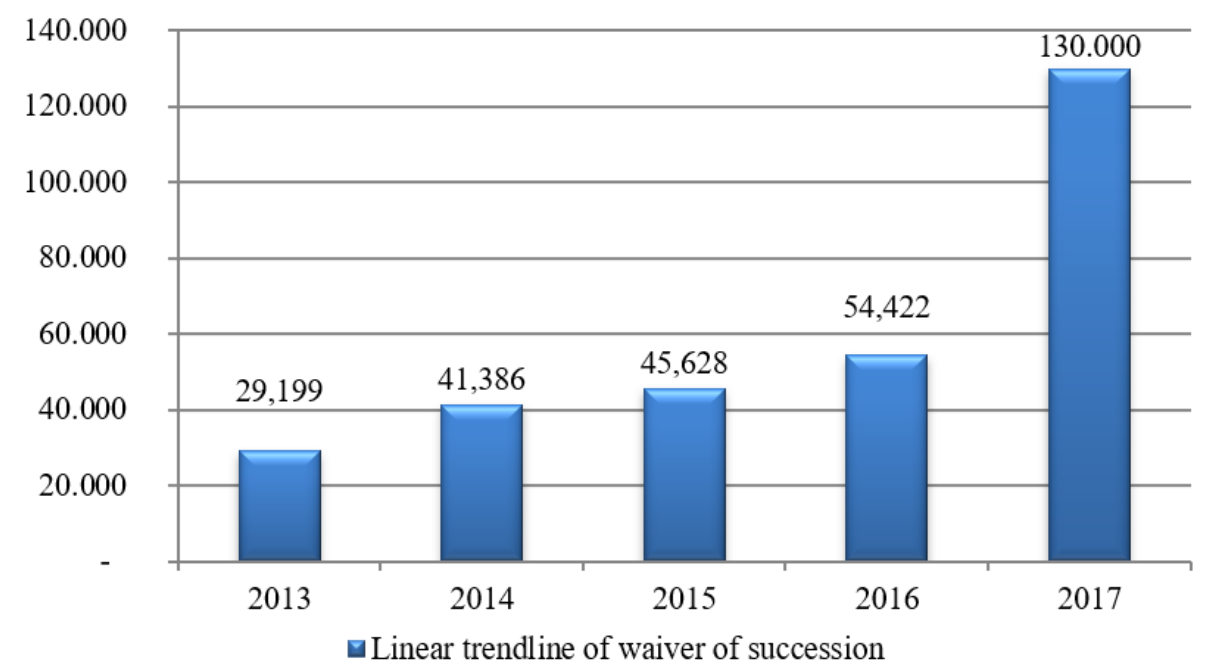

Figure 6. Waiver of succession in Greece (2019-2017)

Source: Ministry of Justice, Transparency and Human Rights 2017 
Moreover, apart from the tremendous rise in inheritance renunciations, the state increasingly proceeds to enforcement measures against taxpayers who cannot pay private debts to tax authorities. These measures have deteriorated the phenomenon of homelessness.

Table 4. Private debt to tax authorities/state, 2009-2016 (Independent Authority for Public Revenue)

\begin{tabular}{lllll}
\hline Year & 2014 & 2015 & 2016 & 2017 \\
\hline Debts & 75 bil. $€$ & 86 bil. $€$ & 95 bil. $€$ & 102 bil. $€$ \\
Taxpayers who owe to tax authorities/state & $3,939,353$ & $4,305,153$ & $4,146,483$ & $4,068,857$ \\
$\begin{array}{l}\text { Enforcement measures against taxpayers: } \\
\text { e.g., seizures, auctions }\end{array}$ & no data & 695,074 & 839,056 & $1,050,077$ \\
\hline
\end{tabular}

Source: Mavridis 2018:10

Table 4 presents the dire situation in Greece. In 2017, the debt to tax agencies was $€ 102$ billion. Furthermore, in 2017 the total number of taxpayers owing to tax authorities reached $4,068,857$ on many $(1,050,077)$ of whom enforcement measures by the state such as seizures and auctions were imposed. This practically means that almost one out of two taxpayers owes to tax authorities. In addition, there are serious problems with private debt, the total bank debt (red loans) and the debt of social security organizations (Mavridis 2018:10). In addition, from 2009 and onwards several households find it difficult to pay off home loans due to regressive reductions in salaries and pensions (Louzis et al. 2011: 22-24, Matsaganis 2013:16).

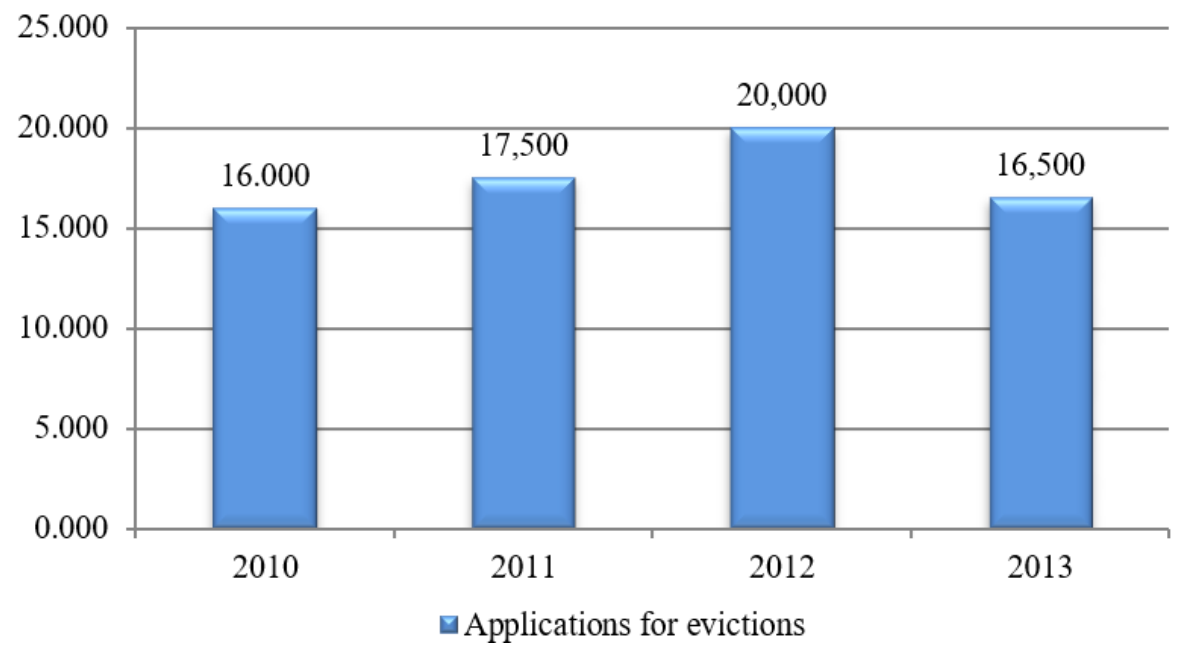

Figure 7. Trends in evictions in Greece, 2010-2013 - Estimations of eviction applications to courts for private rented housing

Source: OECD 2017, authors' editing

Figure 7 shows that in the beginning of the crisis evictions increased. Paradoxically, after 2012 there was clear reduction in evictions.

Both Figure 7 and Table 5 illustrate a paradox. Although the number of homeless people has steadily increased, the number of evictions as well as landlord/tenant disputes has not. A possible answer is that a moratorium has been issued by banks and Greek governments protecting a number of debtors with mortgage arrears (Sapounakis and Katapidi 2017:150). Also, the protective Law 3869/2010 helped many people to avoid bank auctions. The newly elected government of SYRIZA (Coalition of the Radical Left) empowered this trend up to a point when it came to power in 2015. Finally, the decrease of evictions and property lawsuits is possibly due to massive youth immigration abroad as well as to individuals' return of to their parental homes. 
Table 5. Applications to the Court of First Instance of Thessaloniki for landlord/tenant disputes (lawsuits and orders), 2006-2016

\begin{tabular}{llll}
\hline Year & Lawsuits (codes 201-208) & Orders (codes 262-263) & Total \\
\hline 2006 & 1,887 & 75 & 1,962 \\
2007 & 1,889 & 43 & 1,932 \\
2008 & 1,832 & 84 & 1,916 \\
2009 & 2,258 & 392 & 2,650 \\
2010 & 2,559 & 638 & 3,197 \\
2011 & 2,024 & 1,006 & 3,030 \\
2012 & 1,458 & 604 & 2,062 \\
2013 & 1,079 & 545 & 1,624 \\
2014 & 861 & 418 & 1,279 \\
2015 & 908 & 395 & 1,303 \\
2016 & 575 & 349 & 924 \\
\hline
\end{tabular}

Source: Court of First Instance of Thessaloniki

\section{Comparing Previous Surveys on Homelessness in Greece}

The following five surveys were conducted in Greece: two of them were conducted by NGO Klimaka (2006 and 2012) in certain areas of Greece, another two surveys were conducted under the supervision of KYADA (2013 and 2016) in Athens and one survey was conducted in seven Municipalities of Greece on May 2018 under the supervision of Panteion University of Athens and the Ministry of Labour, Social Insurance and Social Solidarity (Panteion University and Ministry of Labour, Social Insurance and Social Solidarity 2018). Klimaka is a private organization established in 2000 with a view to address social problems especially regarding vulnerable groups. On the other hand, the City of Athens Reception and Solidarity Center for the Homeless (KYADA) is a public and social agency which officially belongs to the Municipality of Athens. In particular, in 2006 NGO Klimaka conducted a survey by questioning 200 homeless people from March 2015 until March 2016 (Klimaka 2016). In 2012, NGO Klimaka conducted anew a similar survey by questioning 214 homeless people (NGO Klimaka 2012 in Theodorikakou et al. 2012). In 2013 a similar survey was conducted and presented by the City of Athens Reception and Solidarity Center for the Homeless (KYADA) by questioning 480 homeless people from June to August 2013 (KYADA 2013). Furthermore, in 2016 KYADA presented a survey, funded by the Norwegian government, after questioning 451 homeless people from March 2015 until March 2016 (KYADA 2016). Finally, Panteion University and Ministry of Labour, Social Insurance and Social Solidarity conducted a survey by questioning 1,645 homeless people in 2018 (Panteion University and Ministry of Labour, Social Insurance and Social Solidarity 2018).

\subsection{Gender}

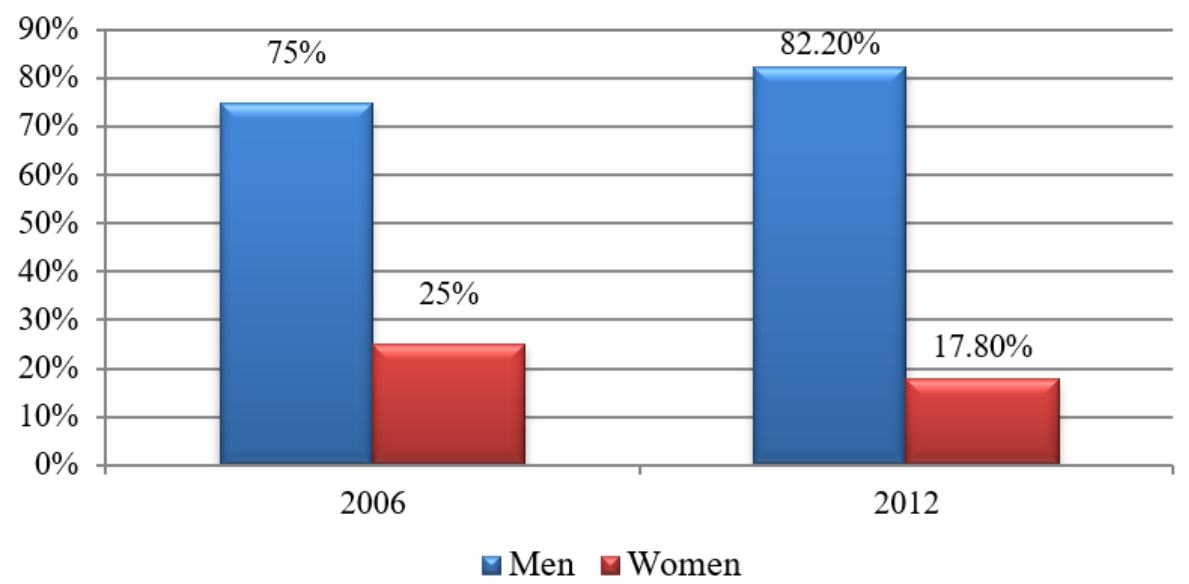

Figure 8. Gender, NGO Klimaka 2006, 2012

Source: NGO Klimaka 2006, 2012, authors' editing 
Men are usually more than women among the homeless. In the years following the outburst of the crisis homelessness seems to be more of a men's problem (Panteion University and Ministry of Labour, Social Insurance and Social Solidarity 2018). As emphasized in Figure 8, in 2006 25\% of the homeless were women and $75 \%$ men (NGO Klimaka 2006, 2012). Similarly, in KYADA surveys in Athens, homeless men are more, namely $77 \%$ in 2013 and $85.4 \%$ in 2016. All surveys show a clear rise in homeless men.

7.2 Age

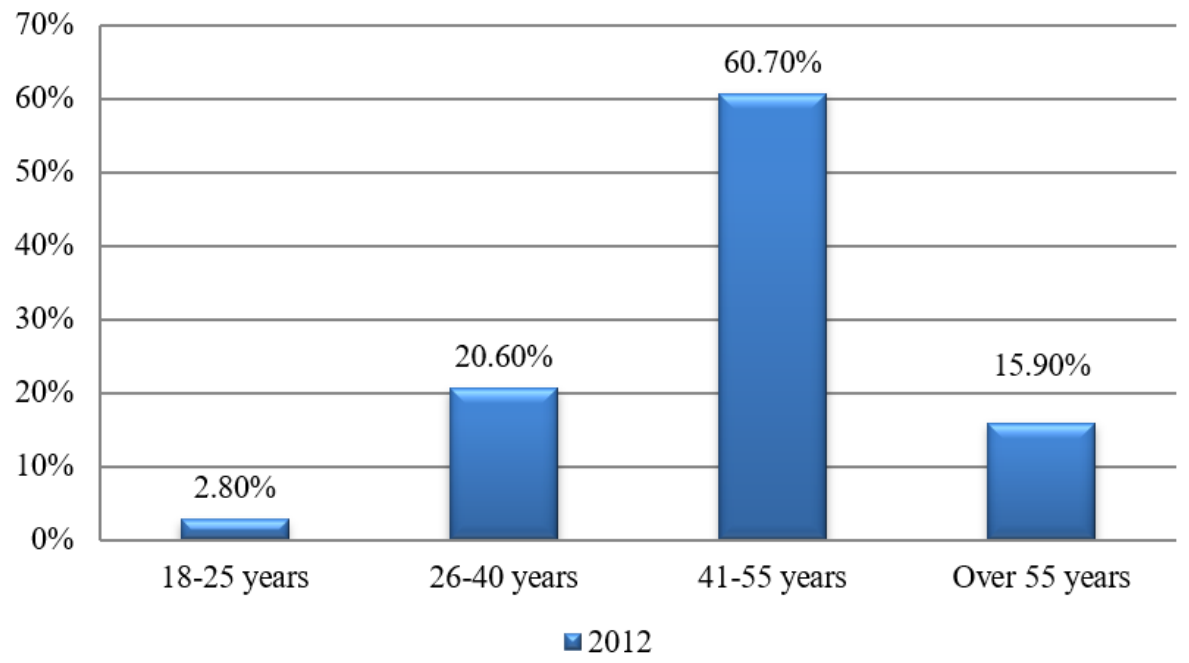

Figure 9. Age, NGO Klimaka, 2012

Source: NGO Klimaka 2012, authors' editing

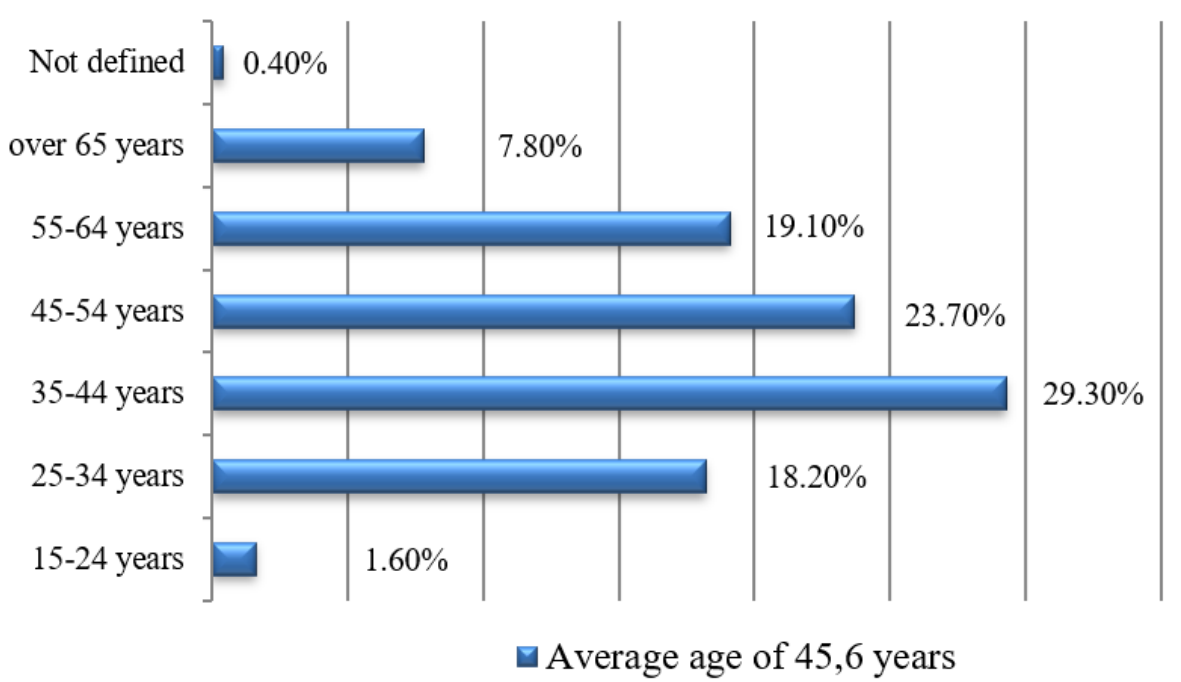

Figure 10. Age, KYADA, 2016

Source: KYADA 2016, authors' editing

At first, it should be noted that certain data should not be mixed in one diagram for statistical reasons. The surveys of Klimaka (2012) and Kyada (2016) clearly show that the majority of the homeless are over 40 years of age (Figure 9, Figure 10). Furthermore the survey of Panteion University and the Ministry of Labour, Social Insurance and Social Solidarity (2018) shows that the majority of the homeless are between 18-44 years of age. A possible explanation is a job loss or an economic failure in relation to parental death (parental support is traditional in Greece), especially in the Mediterranean countries. 


\subsection{Homelessness Duration}

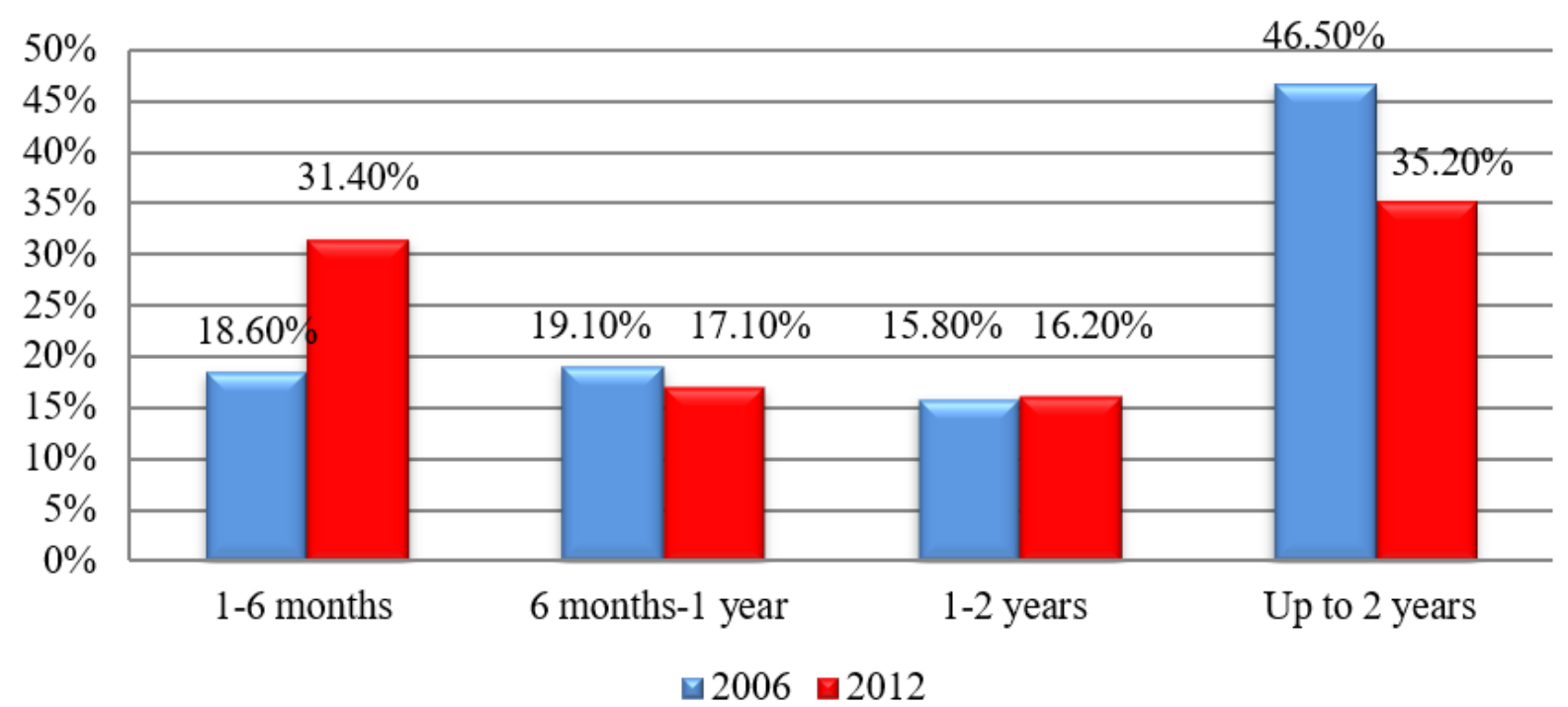

Figure 11. Homelessness Duration, NGO Klimaka, 2006, 2012

Source: NGO Klimaka, 2006, 2012, authors' editing

Figure 11 shows how the economic crisis has directly affected the homeless population. In 2012, in the beginning of the crisis, people who were homeless 1-6 months almost doubled in relation to 2006. The newcomers reached from $18.60 \%$ of the total homeless population in 2006 to $31.40 \%$ in 2012 . Another serious problem is that the number of people who remain homeless for a period of up to 2 years is considerably high (Klimaka 2006, 2012, KYADA 2016).

\subsection{Education}

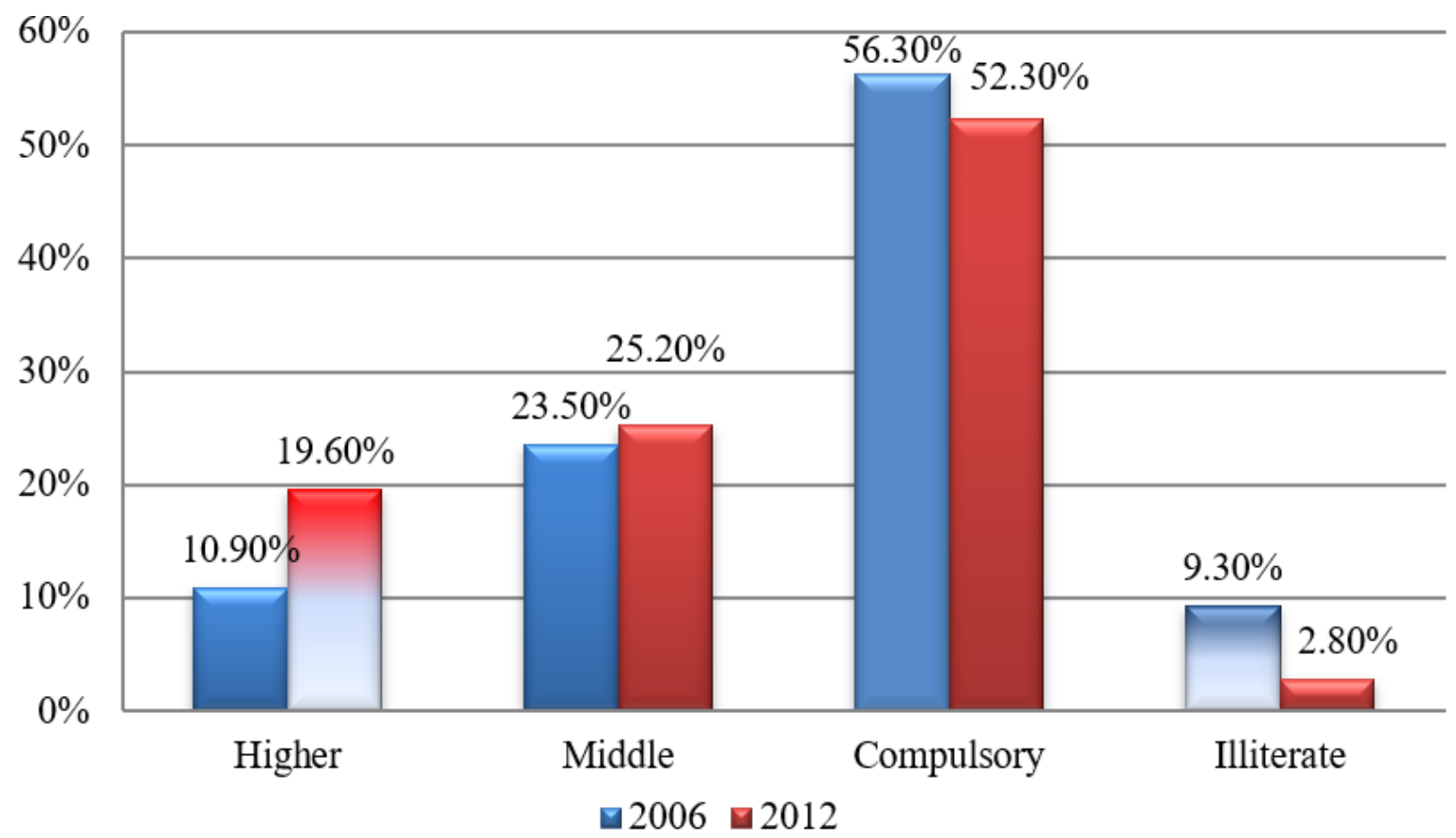

Figure 12. Education, NGO Klimaka, 2006, 2012

Source: NGO Klimaka 2006, 2012, authors' editing 
Data in Figure 12 confirms that in 2012 the homeless population is more educated than in 2006. It is normal over the years that people are more educated. On the other hand, it appears that the low educational level is a typical characteristic of homeless people. The state, therefore, should focus on skill-learning for the homeless as a practical method to reduce homelessness (NGO Klimaka 2006, 2012).

\subsection{Causes of Homelessness}

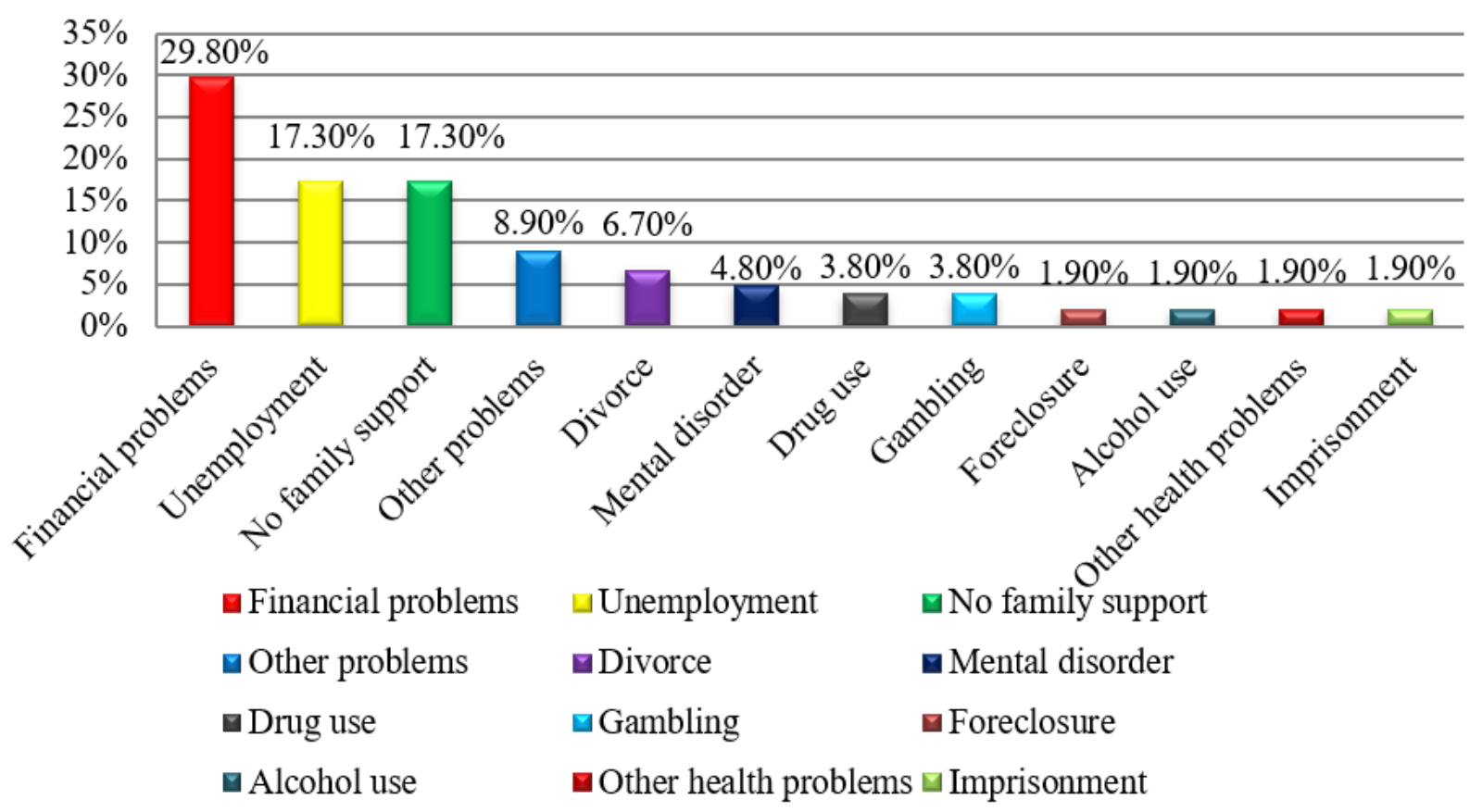

Figure 13. Causes of homelessness, NGO Klimaka, 2012

Source: NGO Klimaka 2012, authors' editing

The three main causes for homelessness are constantly: a) financial problems $(29.80 \%)$, b) unemployment (17.30\%) and the lack of family support (17.30\%), which total 64.4\% (NGO Klimaka 2016). The above three factors are exactly the same in the previous survey of Klimaka conducted in 2006. The survey of KYADA (2013) confirms Klimaka's data of 2006 and 2012 (Figure 13). It is clear that economic (unemployment) and financial problems are the major factors which trigger homelessness ( $47.1 \%$ in total). Apart from that, family breakdowns and personal isolation from family (namely no family support and divorces) play a secondary role which cannot be considered to be negligible ( $24 \%$ in total). On the other hand, serious addictions, such as drug use, gambling and alcohol, account only for $9.5 \%$, which is relatively low. Finally, the complexity of the causes of homelessness is visible as $8.9 \%$ of the respondents selected the vague category "other problems".

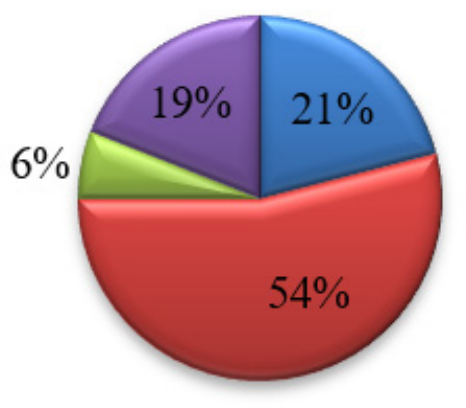

\section{$\square$ No family support $\square$ Financial problems $\square$ Free Choice $\square$ No answer}

Figure 14. The causes of homelessness, KYADA, 2013

Source: KYADA 2013, authors' editing 


\subsection{Familial Attitude}

Unfortunately, in Greece the traditional Mediterranean family model became westernized very rapidly. As a result solidarity among family members has weakened. When the debt crisis broke out, the problem of lack of solidarity became obvious. The weakening of familial safety clearly worsened housing conditions (Papadopoulos and Roumpakis 2012:209, 219-220, 2013:211-212).

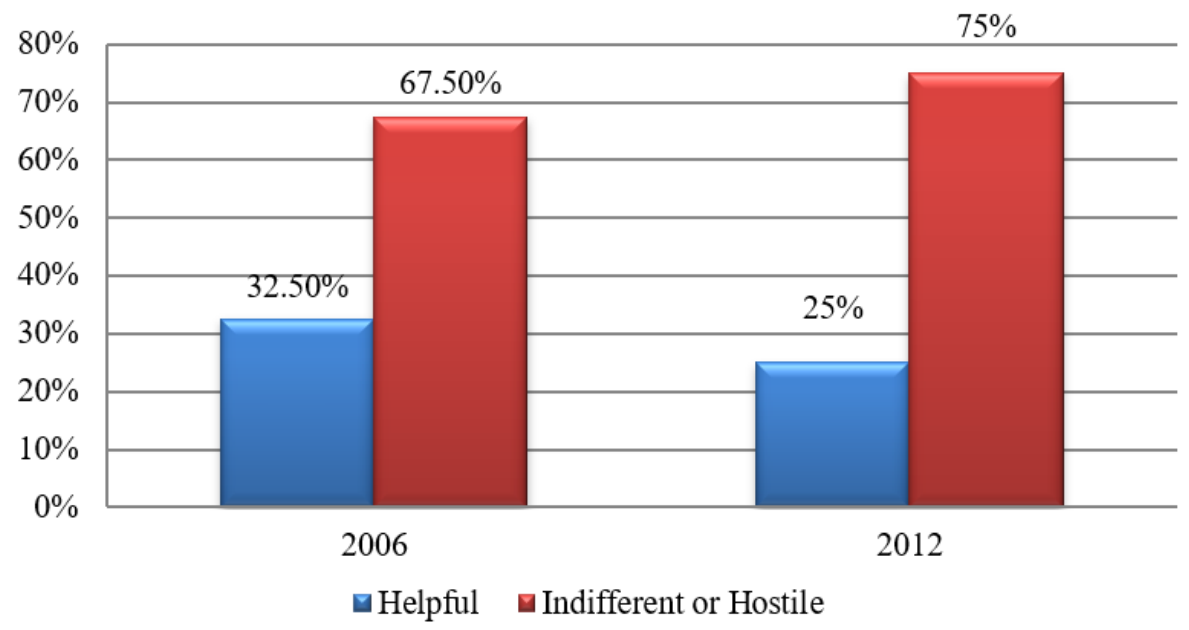

Figure 15. Familial attitude, NGO Klimaka, 2006, 2012

Source: NGO Klimaka 2006, 2012, authors' editing

Figure 15 depicts the tranfromation of society into a more faceless and untouchable form. Specifically, during the last economic crisis, familial attitude towards the potentially homeless has dramatically worsened. In 2012 three quarters of relatives $(75 \%)$ tend not to support family members who become homeless. Unfortunately, the family structure rapidly lost its prestige even in Mediteranean states such as Greece. Between 2006 and 2012 familial attitude towards homeless relatives became significantly worse by $7.5 \%$ (NGO Klimaka 2006, 2012). Similarily, in 2016, according to the survey of KYADA (2016), the percentage of supportive relatives amounted only to $25.5 \%$.

\subsection{Health Insurance}

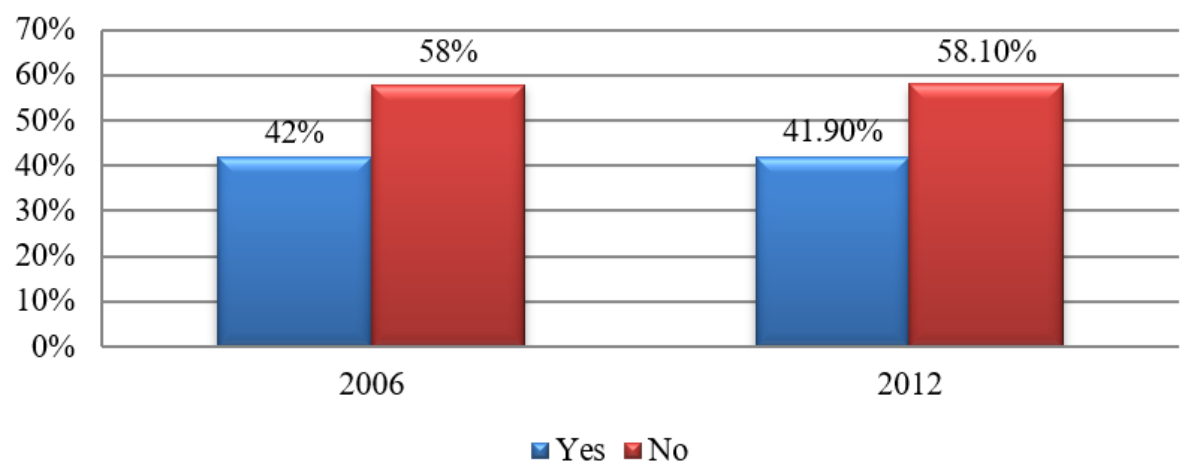

Figure 16. Health insurance, NGO Klimaka, 2006, 2012

Source: NGO Klimaka 2006, 2012, authors' editing

Figure 16 points out the failure of social programs combating homelessness. Unfortunately, the state not only is incapable of finding appropriate accommodation for the homeless but cannot even provide the necessary medical assistance. Homeless people excluded from health insurance have steadily accounted for a percentage of $58 \%$. What is worse, the areas where the homeless live are usually disease hotbeds. 


\subsection{Begging}

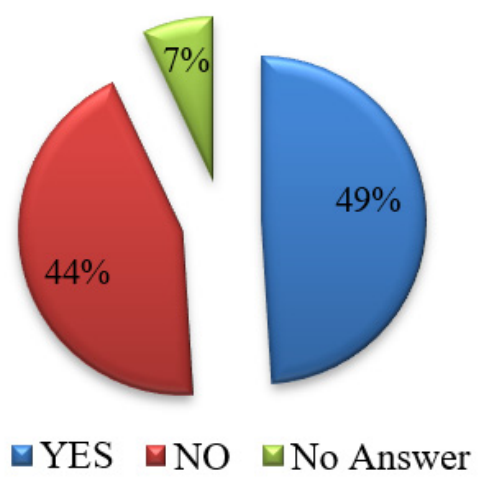

Figure 17. Begging, KYADA, 2013

Source: KYADA 2013, authors' editing

Unfortunately, according to KYADA's data (2013), almost one in two (49\%) of the homeless begged (Figure 17). Begging naturally derives from economic obstacles. An additional problem is that begging often entails court proceedings, creating a vicious cycle of isolation and stigmatizing citizens. For example, according to article 407 of the Greek Penal Code, begging is punishable by up to 6 months in jail and up to a $€ 3,000$ fine.

\subsection{Change of Personal Situation}

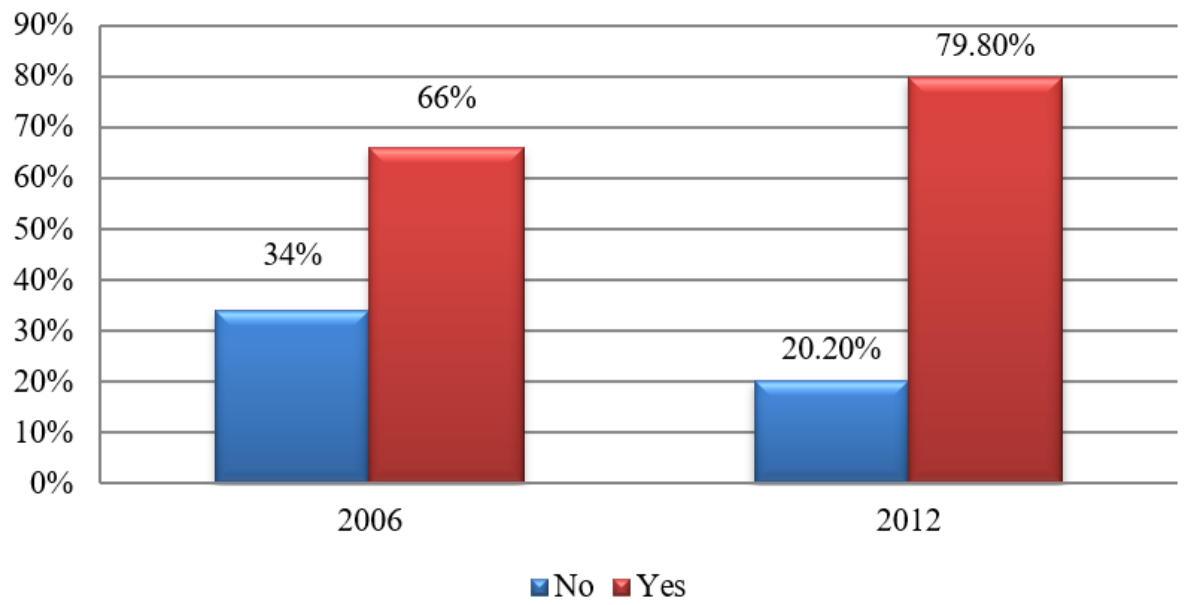

Figure 18. Change of personal situation, NGO Klimaka, 2006, 2012

Source: NGO Klimaka 2006, 2012, authors' editing

Figure 18 clarifies that the homeless became more optimistic in the middle of the economic crisis. In 2012 almost $80 \%$ of homeless people believed that their situation could change (Klimaka 2012). The respective 2006 percentage was approximately $66 \%$. Paradoxically, for the large majority of the homeless their future was promising. A possible answer is that they did not expect the prolongation of the crisis. Unfortunately, up to now, the general economic situation in Greece has drastically deteriorated.

\section{Solutions}

The phenomenon of homelessness is connected with the broader implementation of social policy. In the last decade the Greek economy has significantly deteriorated due to the socio-economic crisis. The crisis obviously affected the Greek welfare state. As a consequence, due to the lack of financial resources, the state apparatus, private organizations and the official Orthodox Church should co-operate with each other in order to eliminate the existence of homeless people, no matter if they are Greek or foreigners. Also, there needs to be close collaboration with European associations and organizations such as FEANTSA. Better management is the only way forward. 
More specifically, at first, specialized shelters should be constructed across the country for the homeless where they will be able to find temporary general help, free medical assistance and food, on a case by case basis. Officially the social shelters would be Open Day Shelters for the Homeless, Dormitories, Transient Hospitality Hostels, and supportive apartments. Moreover, apart from receiving a small monthly benefit, the homeless should have the right to free education in the state educational structures. Unfortunately, there is a strong relation between the lack of education and homelessness. Thirdly, every homeless person should be enrolled in a special state list and all social shelters should be closely interconnected. The purpose behind the interconnection would be to provide every available source of assistance towards homeless people. Finally, there is significant need for additional research, political commitment, strategic planning, investing of fiscal and human resources and voluntary activity.

Unfortunately, up to now, the usually implemented policies have intended to support solely the basic needs of homeless people, such as food. There is a lack of appropriate housing shelters. Furthermore, people, especially those with mental or other disorders, need to be handled in a flexible manner that includes crisis intervention, a well-functioning social safety net and actual housing availability (Busch-Geertsema et al. 2010:5, 71). Tsemberis and Eisenberg (2000:488-489) have suggested a three-stage program called "Continuum of Care", especially for homeless people with mental disorders or addictions. At the first stage, beneficiaries are encouraged to stay in a shelter so as to abandon their former way of living. In the shelter, the homeless receive health services and general aid. In the second phase, they learn to live alone at home and in the final stage, if standards are met, accommodation is provided in places of permanent residence where they receive sufficient support and particular treatment. Another solution is the "Housing First" scheme which is intended to immediately re-house the homeless and then provide other assistance (economic, medical, education technical or even administrative). Of course, the program is organized in a voluntary manner so that people living rough can freely chose whether to participate in the program or leave (Gulcur et al. 2003:182-183).

In Greece, there was an attempt to implement the "Housing First" program in 2015. In 2017 the program was replaced by KEA (Social Solidarity Income) which offers a way out only to vulnerable citizens that are not accommodated by friends or family members. The Achilles heel of the abovementioned programs is bureaucracy. Many times homeless people are unaware of their own rights. What is worse, without additional help homeless people cannot afford the cost of living in houses and as a result they do not easily abandon the streets. Homeless people need proper advice on a regular basis by specialized permanent staff which will "patrol" the streets, helping the homeless.

\section{Conclusions}

The traditional weakness of the Greek welfare state in relation with the continuous welfare cuts introduced during the crisis has significantly reduced household incomes. Even middle income households have to cope with precarious jobs or unemployment. In Greece cuts, economic stagnation, as well as the high housing costs, have increased homelessness. In addition, the replacement of family as a social safety net has further aggravated the situation of homeless people.

Despite the fact that the reasons for which people sleep rough have not changed during the crisis (e.g. economic reasons, unemployment and lack of family support), the personal profile of the homeless has changed. After the crisis, men are affected more than women and young people more than older people. Even more, university graduates end up on the streets more often than before the emergence of the crisis. Moreover, the group of immigrants or refugees has gradually increased the homeless population, especially the vulnerable group which resides in non-decent accommodation. Regarding the duration of homelessness it seems that after the crisis it has increased up to six months.

Consequently, it is evident that the governments during the last recession could not solve or contain the problem of homelessness. Governmental countermeasures have only been temporary and fragmented. Therefore, the adopted countermeasures have been ineffective. The failure to cope with the rise of homelessness is probably correlated with the lack of data and resources, weak personalization approaches and inadequate policy design. However, the legal framework for the protection of the main residence has acted as an obstacle to a further increase in the rate of the homeless.

\section{Acknowledgments}

The authors would like to thank the reviewers of this journal for their suggestions that improved the presentation of the herein discussed topic. 


\section{References}

Arapoglou, V., \& Gounis, K. (2014). Final Report: Caring for the Homeless and the Poor in Greece: Implications for the Future of Social Protection and Social Inclusion. Retrieved April 14, 2018, from http://www.lse.ac.uk/Hellenic-Observatory/Assets/Documents/Research/External-Research-

Projects/Arapoglou-Gounis.pdf

Arapoglou, V., \& Kostas, G. (2015). Poverty and Homelessness in Athens: Governance and the Rise of an Emergency Model of Social Crisis Management. Hellenic Observatory Papers on Greece and Southeast Europe. GreeSE Paper No. 90. March. Retrieved April 14, 2018, from http://www.lse.ac.uk/europeanInstitute/research/hellenicObservatory/CMS\%20pdf/Publications/GreeSE/Gr eeSE_No90.pdf

Arapoglou, V., Gounis, K., Siatitsa, D., \& Soulele, D. (2015). Social insecurity and lack of hosing in Athens, Studies 39, Athens: INE, October. Retrieved April 14, 2018, from http://ineobservatory.gr/wpcontent/uploads/2015/12/MELETH-39.pdf

Busch-Geertsema, V, Edgar, W., O’ Sullivan, E., \& Pleace, N. (2010). Homelessness and Homeless Policies in Europe: Lessons from Research. European Consensus Conference on Homelessness (09-10 December 2010), pp. 1-96. Retrieved April 19, 2018, from http://noticiaspsh.org/IMG/pdf/4099_Homeless_Policies_Europe_Lessons_Research_EN.pdf

Chamberlain, C., \& Mackenzie, D. (1992). Understanding contemporary homelessness: Issues of definition and meaning. Australian Journal of Social Issues, 27(4), 274-297. https://doi.org/10.1002/j.18394655.1992.tb00911.x

Daily Star Lebanon. (2012). Some 13,000 homeless in Athens: charity. May 24. Retrieved April 14, 2018, from http://www.dailystar.com.lb/News/International/2012/May-24/174528-some-13000-homeless-in-athenscharity.ashx

DiEM25-GR. (2018). Crisis costs in human lives, not in numbers. March 16. Retrieved April 14, 2018, from https://diem25.org/crisis/

Eddowes, A., \& Hranitz, J. (1989). Educating children of the homeless. Childhood Education, 65(4), 197-200. https://doi.org/10.1080/00094056.1989.10522433

Edgar, B., Meert, H., \& Doherty, J. (2004). Third Review of Statistics on Homelessness in Europe: Developing an operational definition on homelessness, November, FEANTSA. Retrieved April 10, 2018, from http://www.feantsaresearch.org/download/3-20041762990330054027965.pdf

FEANTSA. \& The Foundation Abbé Pierre. (2017). Second Overview of Housing Exclusion in Europe. FEANTSA and the Foundation Abbé Pierre. Retrieved April 12, 2018, from http://www.feantsa.org/download/gb_housing-exclusion-report_complete_20178613899107250251219.pdf

FEANTSA. \& The Foundation Abbé Pierre. (2018). Third Overview of Housing Exclusion in Europe. FEANTSA and the Foundation Abbé Pierre. Retrieved April 15, 2018, from http://www.feantsa.org/download/full-reporten1029873431323901915.pdf

FEANTSA. (2006). ETHOS - TAKING STOCK. Retrieved October 4, 2018, from http://www.feantsa.org/download/ethospaper20063618592914136463249.pdf

FEANTSA. (2012). On the way home? FEANTSA Monitoring Report on Homelessness and Homeless Policies in Europe. Retrieved April 10, 2018, from http://www.feantsa.org/download/on_the_way_home16908290734892551038.pdf

FEANTSA. (2017a). Feantsa's Manifesto to end homelessness. Retrieved April 10, 2018, from http://www.feantsa.org/download/manifesto-for web1356377830689997508.pdf?force=true

FEANTSA. (2017b). Homelessness in Greece. Retrieved April 14, 2018, from http://www.feantsa.org/download/greece-20172928673074328238317.pdf

Fitzpatrick, S., Hal, P., Glen, B., \& Steve, W. (2012). The Homelessness Monitor: England 2012. Institute for Housing, Urban and Real Estate Research, Heriot-Watt University and Centre for Housing Policy, University of York, pp.1-136. Retrieved April 19, 2018, from https://www.crisis.org.uk/media/237045/the_homelessness_monitor_england_2012.pdf

Fitzpatrick, S., Hal, P., Glen, B., Steve, W., \& Beth, W. (2017). The Homelessness Monitor: England 2017. Institute for Social Policy, Environment and Real Estate, (I-SPHERE) Heriot-Watt University; City Futures Research 
Center, and University of New South Wales, pp. 1-126. Retrieved April 19, 2018, from https://www.yhne.org.uk/wp-content/uploads/Homelessness-Monitor-England-2017_FINAL.pdf

Fondeville, N., \& Ward, T. (2011). Homelessness during the crisis. Research note 8/11, November, European Commission. Retrieved April 13, 2018, from http://ec.europa.eu/social/BlobServlet?docId=9847\&langId=en

Gulcur, L., Stefanci,c A., Shinn, M., Tsemberis, S., \& Fischer, S. (2003). Housing Hospitalization, and Cost Outcomes for Homeless Individuals with Psychiatric Disabilities in Continuum of Care and Housing First Programmes. Journal of Community and Applied Social Psychology, 13, 171-176. https://doi.org/10.1002/casp.723

Jencks, C. (1994). The Homeless. Cambridge: Harvard University Press.

Kottasova, I. (2015). Greece crisis: Sleeping on the streets of Athens, CNN Money, July 12. Retrieved April 14, 2018, from http://money.cnn.com/2015/07/12/news/economy/greece-crisis-homeless/index.html

Kouros, G.(2018). Debts and seizures are strangling the market", Naftemporiki.gr. February 2. Retrieved April 13, 2018, from http://m.naftemporiki.gr/story/1317332/xrei-kai-katasxeseis-pnigoun-tin-agora

KYADA. (2013). Basic conclusions of recording of homeless. Retrieved April 14, 2018, from http://courses.arch.ntua.gr/fsr/145465/KYADA\%20homeless\%20Oct13.pdf

KYADA. (2016). Fighting Poverty and Social Exclusion. Retrieved April 14, 2018, from http://slideplayer.gr/slide/11255844/

Larimer, M., Malone, D., Garner, M. Atkins, D., Burlingham, B., Lonczak, H., Tanzer, K., Ginzler, J., Clifasefi, S., Hobson, W., \& Marlatt, A. (2009). Health Care and Public Service Use and Costs before and after Provision of Housing for Chronically Homeless Persons with Severe Alcohol Problems. JAMA, 301, 13491357. https://doi.org/10.1001/jama.2009.414

Louzis, D., Vouldis, A., \& Metaxas, V. (2011). Macroeconomic and Bank-specific Determinants of NonPerforming Loans in Greece: A Comparative Study of Mortgage, Business and Consumer Loan Portfolios. Journal of Banking and Finance xxx, pp. 1-44. Retrieved April 26, 2018, from https://www.bankofgreece.gr/BogEkdoseis/Paper2010118.pdf

Matsaganis, M. (2013). The Greek crisis: Social Impact and Social Responses" Friedrich Ebert Stiftung Study, pp. 1-40. Retrieved May 3, 2018, from http://library.fes.de/pdf-files/id/10314.pdf

Mavridis, S. (2018). Greece's Economic and Social Transformation 2008-2017', Soc. Sci., 7(1), 9, Special Issue Selected Papers from the 9th Slovenian Social Science Conference on "Social Transformations: The Global and the Local, Ljubljana, Slovenia, 21-23 September 2017. https://doi.org/10.3390/socsci7010009

McNaughton, C. (2008). Transitions through homelessness. Lives on the edge. New York: Palgrave Macmillan. https://doi.org/10.1057/9780230227347

Migreurope. (2017). City Plaza Hotel: A landmark of solidarity in Athens. Atlas des Migrants, December 25. Retrieved April 14, 2018, from http://www.migreurop.org/article2853.html

Ministry of Justice. (2017). Transparency and Human Rights. Retrieved April 14, 2018, from http://www.iefimerida.gr/sites/default/files/apopoiiseisklironomion.pdf

Minnery, J., \& Greenhalgh, E. (2007). Approaches to Homelessness Policy in Europe, the United States, and Australia. Journal of Social Issues, 63, 641-645. https://doi.org/10.1111/j.1540-4560.2007.00528.x

Mpoulia, E. (2011). Homeless: Routes have their own history. In2life.gr, December 21. Retrieved April 14, 2018, from http://www.in2life.gr/everyday/modernlife/article/214109/astegoi-oi-dromoi-ehoyn-tis-dikes-toysistories.html

Murphy, J., \& Tobin, K. (2011). Homelessness comes to school. Thousand Oaks: Corwin.

NGO Klimaka. (2006). Homeless in Greece. Retrieved April 14, 2018, from http://docplayer.gr/2174213-Ereynaastegoi-stin-ellada-psyhokoinoniko-profil-kai-synthikes-diaviosis-sto-dromo.html

NGO Klimaka. (2012) see in Theodorikakou et al. (2012).

OECD. (2017). Affordable Housing Database Evictions. Retrieved April 17, 2018, from https://www.oecd.org/els/family/HC3-3-Evictions.pdf

Panteion University and Ministry of Labour, Social Insurance and Social Solidarity (2018). Register of homeless people on the streets and on supportive, municipal structures. Retrieved June 18, 2018, from 
https:/government.gov.gr/wp-content/uploads/2018/07/\%CE\%91\%CE\%A1\%CE\%A7\%CE\%99\%CE\%9A\% CE\%91-\%CE\%91\%CE\%A0\%CE\%9F\%CE\%A4\%CE\%95\%CE\%9B\%CE\%95\%CE\%A3\%CE\%9C\%CE\% 91\%CE\%A4\%CE\%91-\%CE\%9C\%CE\%AC\%CE\%B7\%CF\%82-2018-2-1.pdf

Papadopoulos, T., \& Roumpakis, A. (2013). Familistic Welfare Capitalism in Crisis: Social Reproduction and AntiSocial Policy in Greece. Journal of International and Comparative Social Policy, 29, 204-224. https://doi.org/10.1080/21699763.2013.863736

Papadopoulos, T., Roumpakis, A. (2012). The Greek Welfare State in the Age of Austerity: Anti-social Policy and the Politico Economic Crisis. In Kilkey Majella, Ramia Gaby, Farnsworth Kevin (eds). Social Policy Review, 24, 203-227. The Policy Press. https://doi.org/10.2307/j.ctt9qgxc6.16

Petmesidou, M. (2011). Pensions, Health and Long-term Care, Annual National Report-Greece Asisp, pp.1-40. Retrieved March 10, 2018, from http://pensionreform.ru/files/4037/ASISP.\%20Annual\%20National\%20 Report\%202011\%20-\%20Greece.pdf

Petmesidou, M. (2013a). Destructive Austerity and the Specter of "Immiseration" in the EU Periphery" CROP Briefs Series, pp. 1-8.

Petmesidou, M. (2013b). Is Social Protection in Greece at a Crossroads? Special Issue of European Societies, 15(4), $1-18$.

Petmesidou, M. (2014). Pensions, Health and Long-term Care, Annual National Report-Greece Asisp, pp. 1-49. Retrieved March 10, 2018, from http://socialprotection.eu/files_db/1224/asisp_ANR12_Greece.pdf

Petmesidou, M. (2012). Pensions, Health and Long-term Care. Annual National Report-Greece Asisp, pp. 1-42. Retrieved March 10, 2018, from http://pensionreform.ru/files/13639/ASISP.\%20Annual\% 20National\%20Report\%202012\%20-\%20Greece.pdf

Ravenhill, M. (2008). The culture of homelessness. Hampshire: Ashgate Publishing Limited.

Reuters. (2011). Rapid increase of homeless in Greece, Newbeast, September 14. Retrieved April 14, 2018, from https://www.newsbeast.gr/greece/arthro/229283/ragdaia-auxisi-ton-astegon-stin-ellada

Roth, D., Toomey, B., \& First, R. (1992). Gender, racial, and age variations among homeless persons, in Robertson, M. and Greenblatt, M. (eds.) Homelessness: A National Perspective. New York: Plenum Press.

Saltou Evi (2016). Homeless: The ... 'unseen' population of Greece. Ta NEA (The News), November 27. Retrieved April 13, 2018, from http://www.tanea.gr/news/greece/article/5409529/astegoi-o-aoratos-plhthysmos-thselladas/

Sapounakis, A., \& Katapidi, I. (2017). Evictions from Primary Residences in Greece: Methodological Concerns Regarding the Collection of Data from Civil Courts' Records for Tenancies. European Journal of Homelessness, Research Notes, part D, 11(2), 149-162. Retrieved April 17, 2018, from http://www.feantsaresearch.org/download/research-note-18654456556474532517.pdf

Stamatis, G. (2012). Homeless in Greece in the Current Financial Crisis. What Perspectives?, Review Article, May. Athens. Retrieved April 12, 2018, from http://crisis.med.uoa.gr/elibrary/13.pdf

Theodorikakou, O., Alamanou, A., \& Katsadoros, K. (2013). Neo-homessness and the Greek Crisis. European Journal of Homelessness, Policy Reviews, part B, 7(2), December, 203-210. Retrieved April 13, 2018, from https://web.archive.org/web/20160314045312/http://feantsaresearch.org/IMG/pdf/ot_et_al_review.pdf

Theodorikakou, O., Alamanou, A., Stamatogiannopoulou, E., Tourkou, A., Karydi, K., Sarantidis, D., \& Katsadoros K. (2012). Homelessness in Greece - 2012: An In-depth Research on Homelessness in the Financial Crisis", Paper Presented at the European Research Conference Access to Housing for Homeless People in Europe, York, 21 ${ }^{\text {st }}$ September 2012. Retrieved April 13, 2018, from https://www.slideserve.com/kioshi/homelessness-in-greece-2012-an-in-depth-research-on-homelessness-inthe-financial-crisis

Toro, P. (2007). Toward an international understanding of homelessness. Journal of Social Issues, 63, 461-482. https://doi.org/10.1111/j.1540-4560.2007.00519.x

Tsemberis, S, \& Eisenberg, R. (2000). Pathways to Housing: Supported Housing for Street- Dwelling Homeless Individuals with Psychiatric Disabilities. Psychiatric Services, 51, 487-493. https://doi.org/10.1176/appi.ps.51.4.487

United Nations Economic Commission for Europe. (2009) Enumeration of homeless people. Retrieved April 14, 
2018, from https://unstats.un.org/unsd/censuskb20/Attachments/2009MPHASIS_ECE_HomelessGUID25ae612721cc4c2c87b536892e1ed1e1.pdf

Void Network. (2013). Down and Out in Athens, Documenting the unemployed and homeless in Greece, September 24. Retrieved April 14, 2018, from http://voidnetwork.gr/2013/09/24/down-and-out-in-athensdocumenting-the-unemployed-and-homeless-in-greece-a-photo-journal-by-yannis-behrakis/

Walks, A. (2006). Homelessness, housing affordability, and the new poverty. In Bunting, T. \& Filion P. (eds.) Canadian cities in transition. Don Mills, ON: Oxford University Press.

Wyly, E., \& Hammel, D. (2005). Mapping neo liberal American urbanism. In Gary Bridge, G., \& Atkinson, R. (eds.) Gentrification in a global context: the new urban colonialism. New York: Routledge. https://doi.org/10.4324/9780203392089_chapter_2

Zarafonitou, C. (2012). Victimization, insecurity and registration of the needs of the homeless people of the Municipality of Kallithea, July. Retrieved April 14, 2018, from http://docplayer.gr/1032834-Thymatopoiisianasfaleia-kai-katagrafi-anagkon-ton-astegon-toy-dimoy-kallitheas.html

\section{Electronic Sources}

Eurostat. Retrieved from http://ec.europa.eu/eurostat/data/database

OECD. Retrieved from http://www.oecd.org/

\section{Copyrights}

Copyright for this article is retained by the author(s), with first publication rights granted to the journal.

This is an open-access article distributed under the terms and conditions of the Creative Commons Attribution license (http://creativecommons.org/licenses/by/4.0/). 